ISSN. 2775-4324 (Online)

Journal of Physical Activity and Sports

Volume 2, Nomor 3, Desember 2021, 329-338

\title{
Efektivitas Permainan Engklek Terhadap Pembelajaran Daring Materi Lompat Jauh Pada Siswa Sma N 1 Kaliwungu
}

\author{
Awang Aji Pradana \\ Pendidikan Jasmani Kesehatan dan Rekreasi. Universitas PGRI Semarang, 50166, Indonesia. \\ awangajipradana12@gmail.com
}

\begin{abstract}
The background in this research is that the Covid-19 outbreak has an impact on the education system, which was initially face-to-face learning, now it has turned into online learning, making teachers have to do sports learning activities online. The formulation of the problem in the study is is there an effect of learning outcomes using the crank learning model on long jump online learning. The purpose of this study was to determine the effectiveness of the crank game on online learning of long jump material. This research was conducted using a quantitative approach using the one group pretest-posttest design method. All data were analyzed using the T statistical test. The sampling technique was carried out by total sampling, the sample in this study amounted to 30 students of SMA N 1 Kaliwungu. The results of the research on the effectiveness of the crank game on online learning of the long jump material show that the Sig. $(0.000)<\alpha(0.05)$. The results of the pretest mean value long jump 78,133 . The results of the posttest mean score long jump 90.383. There was an increase in learning outcomes from pretest to posttest $15.68 \%$. The results of the Gain score obtained a percentage of $56.02 \%$. The results of the pretest mean score of students' pretest responses were $89.33 \%$. The results of the average value of the pretest students' responses to the posttest were $92.33 \%$. So in this study it can be concluded that there is an effect of giving the crank game on online learning material long jump which can increase the squat style long jump. The suggestion in this research is that teachers should make more use of traditional games for learning.
\end{abstract}

Keywords: The Effectiveness of Engklek, Long Jump, Online Learning Games.

\begin{abstract}
Abstrak
Latar belakang dalam penelitian ini adalah wabah covid-19 memberikan dampak terhadap sistem pendidikan yang awalnya pembelajaran tatap muka, sekarang berubah menjadi pembelajaran secara daring, menjadikan guru harus melakukan kegiatan pembelajaran olahraga secara online. Rumusan masalah dalam penelitian adalah adakah pengaruh hasil belajar menggunakan model pembelajaran engklek terhadap pembelajaran daring lompat jauh. Tujuan penelitian ini untuk mengetahui efektivitas permainan engklek terhadap pembelajaran daring materi lompat jauh. Penelitian ini dilakukan dengan menggunakan pendekatan kuantitatif yang menggunakan metode one group pretest-posttest design, Semua data di analisis menggunakan Uji Statistik T. Teknik pengambilan sampel dilakukan dengan total sampling, sampel dalam penelitian ini berjumlah 30 siswa SMAN 1 Kaliwungu. Hasil Penelitian efektivitas permainan engklek terhadap pembelajaran daring materi lompat jauh di peroleh bahwa nilai Sig. $(0,000)<\alpha(0.05)$. Hasil nilai rata - rata pretest lompat jauh 78,133 . Hasil nilai rata rata posttest lompat jauh 90,383. Terjadi peningkatan hasil belajar dari pretest ke posttest 15,68\%. Hasil dari skor Gain diperoleh persentase sebesar 56,02\%. Hasil nilai rata - rata pretest tanggapan siswa pretest 89,33\%. Hasil nilai rata - rata pretest tanggapan siswa posttest 92,33\%. Maka dalam penelitian ini dapat disimpulkan bahwa terdapat pengaruh pemberian permainan engklek terhadap pembelajaran daring materi lompat jauh dapat meningkatkan lompat jauh gaya jongkok. Saran dalam penelitian ini adalah guru harus lebih memanfaatkan permianan tradisional untuk pembelajaran.
\end{abstract}

Kata kunci: Efektivitas Permainan Engklek, Lompat Jauh, Pembelajaran Daring 


\section{PENDAHULUAN}

Berdasarkan Undang-Undang No. 3 Tahun 2005 Pasal 1 menyebutkan bahwa keolahragaan nasional adalah keolahragaan yang berdasarkan Pancasila dan Undang-Undang Dasar Negara Republik Indonesia Tahun 1945 yang berakar pada nilai-nilai keolahragaan, kebudayaan nasional Indonesia, dan tanggap terhadap tuntutan perkembangan olahraga. Adapun Tujuan dari keolahragaan nasional menurut Undang-Undang No. 3 Tahun 2005 Pasal 4 yang berbunyi "keolahragaan nasional bertujuan memelihara dan meningkatkan kesehatan dan kebugaran, prestasi, kualitas manusia, menanamkan nilai moral dan akhlak mulia, sportivitas, disiplin, mempererat dan membina persatuan dan kesatuan bangsa, memperkukuh ketahanan nasional,serta mengangkat harkat, martabat, dan kehormatan bangsa".

Pendidikan Jasmani Olahraga dan Kesehatan merupakan salah satu mata pelajaran yang dilaksanakan pada jenjang pendidikan dasar, menengah, bahkan pada pendidikan tinggi. Tujuan Pendidikan Jasmani yaitu untuk mengembangkan aspek kebugaran jasmani, keterampilan gerak, keterampilan berpikir kritis, keterampilan sosial, penalaran, stabilitas emosional, tindakan moral dan aspek pola hidup sehat. (Depdiknas Permendiknas No.22 Tahun 2006). Badan Standar Nasional Pendidikan (BSNP), pada Model Silabus Mata Pelajaran Penjas SD 2006, dikemukakan bahwa Pendidikan jasmani olahraga dan kesehatan yang diajarkan di sekolah memiliki peranan penting, yaitu memberikan kesempatan kepada peserta didik untuk melihat langsung dalam berbagai pengalaman belajar melalui aktivitas jasmani, olahraga dan kesehatan yang dilakukan secara sistematis memberikan pengalaman belajar untuk membina pertumbuhan fisik dan pengembangan psikis yang lebih baik, sekaligusmembentuk pola hidup sehat dan bugar sepanjang hayat. (Depdiknas Permendiknas No.22 Tahun 2006).

Sistem pembelajaran daring (dalam jaringan) merupakan sistem pembelajaran tatap muka secara langsung antara guru dan siswa tetapi dilakukan melalui online yang menggunakan jaringan internet. Guru harus memastikan kegiatan belajar mengajar tetap berjalan, meskipun siswa berada di rumah. Solusinya, guru dituntut dapat mendesain media pembelajaran sebagai inovasi dengan memanfaatkan media daring (online). Hal ini sesuai dengan Menteri Pendidikan dan Kebudayaan Republik Indonesia terkait Surat Edaran Nomor 4 Tahun 2020 tentang Pelaksanaan Kebijakan Pendidikan dalam Masa Darurat Penyebaran Corona Virus Disease (COVID-19). Sistem pembelajaran dilaksanakan melalui perangkat personal computer (PC) atau laptop yang terhubung dengan koneksi jaringan internet. Guru dapat melakukan pembelajaran bersama diwaktu yang sama menggunakan grup di media sosial seperti WhatsApp (WA), telegram, instagram, aplikasi zoom ataupun media lainnya sebagai media pembelajaran. Dengan demikian, guru dapat memastikan siswa mengikuti pembelajaran dalam waktu yang bersamaan, meskipun di tempat yang berbeda.

Permainan tradisional engklek adalah harus meloncat kesetiap kotak sampai di ujung terjauh yang biasanya berbentuk setengah lingkaran atau kotak yang besar (Sukirman Darmamulya dkk, 2005). Dari sana dia harus kembali dengan cara melompat lagi di kotak yang terdapat gacuk miliknya, dia harus mengambil gacuk itu dengan tangannya, sementara itu sebelah kakinya harus tetap terangkat dan tidak boleh menyentuh tanah. Kemudian dia harus melanjutkan membawa gacuk tersebut sampai keluar.

Lompat jauh adalah salah satu nomor lompat jauh dalam cabang olahraga atletik. Lompat jauh 
merupakan suatu bentuk gerakan melompat, melayang dan mendarat sejauh-jauhnya. Gerakangerakan dalam lompat jauh tersebut harus dilakukan secara baik dan harmonis tidak diputus putus pelaksanaannya agar diperoleh lompatan sejauh-jauhnya. Tim Bina Karya Guru (2004: 27) menyatakan bahwa lompat jauh gaya jongkok merupakan gaya yang paling mudah dilakukan. Biasanya lompat jauh gaya jongkok digunakan oleh pelompat pemula, Ada 3 macam gaya lompat jauh: lompat jauh gaya jongkok (tuck), lompat jauh berjalan di udara (walking in the air), dan lompat jauh menggantung (hang).

\section{METODE}

Penelitian ini merupakan penelitian kuantitatif dengan menggunakan metode "One Groups Pretest-Posttest Design", yaitu desain penelitian yang terdapat pretest sebelum diberi perlakuan dan posttest setelah diberi perlakuan. Penelitian ini dilakukan secara daring peliti pertama memberikan soal kognitif melalui whatsapp setelah selessai kemudian siswa melakukan lompat jauh dengan permainan engklek dimana siswa menggambar bidang engklek di rumah masing - masing kemudian memainkan dengan cara melompat langsung ke kotak nomor 4 dan 5, jika tidak mampu ke nomor 3 ataupun 2 setelah itu siswa di berikan angket untuk memberikan pendapat saat berimain lompat jauh dengan permainan engklek kemudian setelah itu data terkumpul, maka akan dihitung menggunakan SPSS V.2.

\section{Populasi dan Sampel}

Populasi dalam penelitian ini adalah siswa SMA N 1 Kaliwungu. Dalam penelitian ini peneliti menggunakan purposive sampling, dimana purpoive sampling salah satu teknik sampling non random sampling dimana peneliti menentukan pengambilan sampel dengan cara menetapkan ciri-ciri khusus yang sesuai dengan tujuan penelitian sehingga diharapkan dapat menjawab permasalahan penelitian. Sampel dalam penelitian ini adalah siwa kelas X Ips 1 yang berjumlah 30 siswa, sampel dalam penelitian ini dihitung dengan menggunakan rumus ordinal pairing yaitu ABBA.

\section{Teknik dan Instrumen Pengambilan Data}

Teknik pengumpulan data merupakan langkah yang paling utama dalam penelitian, karena tujuan dari penelitian adalah untuk mendapatkan sebuah data. Tanpa mengetahui Teknik pengumpulan data, maka peneliti tidak akan mendapatkan data yang memenuhi standar yang ditetapkan (Sugiyono, 2016: 308). Teknik pengumpulan data yang digunakan dalam penelitian ini:

1) Observasi

2) Tes hasil belajar

3) Lompat jauh dengan permaianan engklek

4) Angket/ Tanggapan siswa 


\section{Teknik Analisis Data}

Teknik analisis data yang digunakan dalam penelitian ini adalah dengan menggunakan analisis uji- t yang diolah dengan bantuan software SPSS V.22. Sebelum dilakukan uji-t, data dilakukan uji prasyarat terlebih dahulu agar membantu analisis lebih baik. Uji prasyarat ini terdiri dari uji normalitas dan uji homogenitas, yang pada tahap akhirnya dapat di tarik kesimpulan.

\section{HASIL DAN PEMBAHASAN}

Berikut adalah data pretest, posttest dan peningkatan atau selisih dari pretest-posttest hasil belajar hasil belajar siswa SMA N 1 Kaliwungu pada pembelajaran daring materi lompat jauh sebagai berikut:

\section{Tabel 1 Statistik Deskriptif Hasil Belajar Siswa Berdasarkan Aspek Penilaian Psikomotorik}

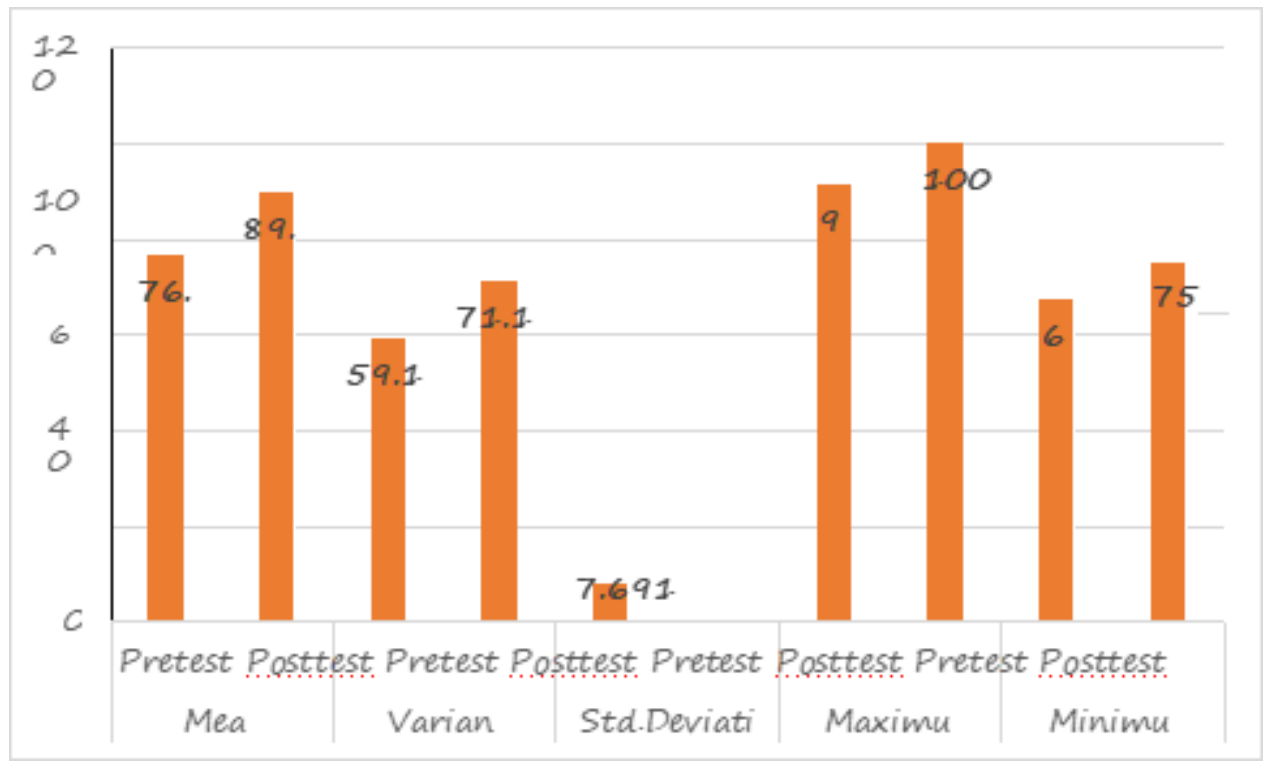


Tabel 2 Statistik Deskriptif Hasil Belajar Siswa Berdasarkan Aspek Penilaian Kognitif

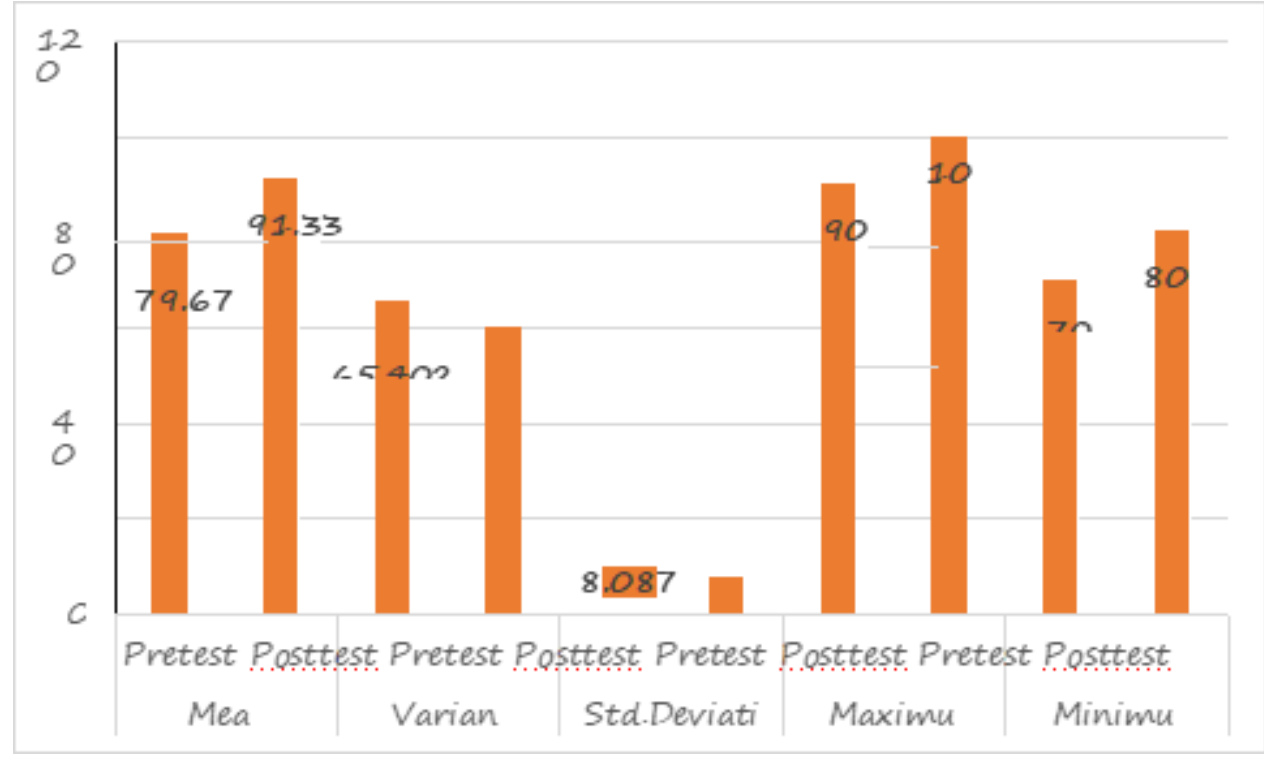

Tabel 3 Statistik Deskriptif Hasil Tanggapan Siswa

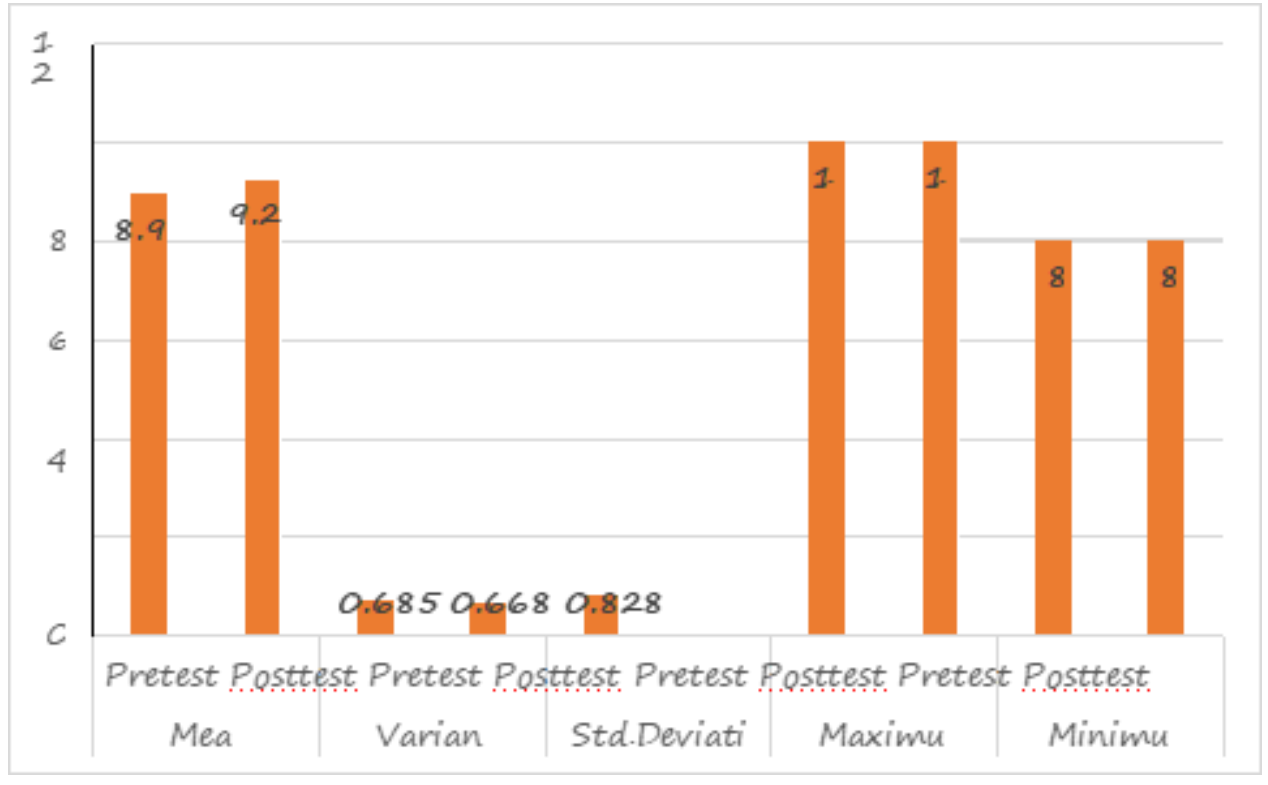


Tabel 4 Kriteria Hasil Skor Tanggapan Siswa

\begin{tabular}{|c|c|c|c|c|}
\hline \multirow{2}{*}{$\begin{array}{c}\text { Item } \\
\text { Pertanyaan }\end{array}$} & $\begin{array}{c}|c| \\
\text { Pkor Tanggapan } \\
\text { Siswa (\%) }\end{array}$ & Kriteria & $\begin{array}{c}\text { Skor Tanggapan } \\
\text { Siswa (\%) }\end{array}$ & Kriteria \\
\hline 1 & 100 & Sangat Kuat & 100 & Sangat Kuat \\
\hline 2 & 97 & Sangat Kuat & 100 & Sangat Kuat \\
\hline 3 & 97 & Sangat Kuat & 97 & Sangat Kuat \\
\hline 4 & 100 & Sangat Kuat & 97 & Sangat Kuat \\
\hline 5 & 77 & Kuat & 80 & Sangat Kuat \\
\hline 6 & 83 & Sangat Kuat & 90 & Sangat Kuat \\
\hline 7 & 87 & Sangat Kuat & 87 & Sangat Kuat \\
\hline 8 & 83 & Sangat Kuat & 93 & Sangat Kuat \\
\hline 9 & 80 & Kuat & 90 & Sangat Kuat \\
\hline 10 & 90 & Sangat Kuat & 90 & Sangat Kuat \\
\hline Total & 89,33 & Sangat Kuat & 92,33 & Sangat Kuat \\
Keseluruhan & & & & \\
\hline
\end{tabular}

\section{Uji Prasyarat Analisis}

Sebelum dilakukan suatu hipotesis diuji, maka terlebih dahulu perlu dilakuakn pengujian prasyarat. Pengujian prasyarat analisis dilakukan didalam penelitian ini menggunakan uji normalitas, uji homogenitas, dan uji pengaruh (uji t). Dari hasil perhitungan stastistik deskripsi diatas tersebut, kemudian dilanjutkan dengan uji persyaratan analisis hipotesis yang meliputi beberapa langkah sebagai berikut.

\section{a) Uji Normalitas Data}

Uji normalitas digunakan untuk mengetahui apakah sampel data berdistribusi normal atau tidak. Uji normalitas data dalam penelitian ini dengan deskriptif stastistik menggunakan kolmogorovSmiornov. Adapun untuk menguji normalitas ini dengan ketentuan jika nilai signifakansi $\geq 0,05$ berarti normal, dan jika nilai signifikansi $\leq 0,05$ berarti tidak normal. Adapun dari hasil perhitungan statistik diperoleh data sebagai berikut. 
Tabel 5 Hasil Uji Normalitas

\begin{tabular}{|l|c|c|c|c|}
\hline Vaiabel & Data & $\begin{array}{l}\text { Kolmogorov } \\
\text { Smirnov } \mathbf{Z}\end{array}$ & $\begin{array}{l}\text { Asymp.Sig (2- } \\
\text { tailed) }\end{array}$ & Keterangan \\
\hline \multirow{3}{*}{ Kognitif } & Pretest & 1,190 & 0,117 & Normal \\
\hline \multirow{3}{*}{ Psikomotorik } & Pretest & 1,285 & 0,074 & Normal \\
\cline { 2 - 5 } Tanggapan & Posttest & 1,153 & 0,082 & Normal \\
\cline { 2 - 5 } Siswa & Pretest & 1,298 & 0,069 & Normal \\
\cline { 2 - 5 } & Posttest & 1,103 & 0,112 & Normal \\
\hline
\end{tabular}

Berdasarkan data dari tabel diatas dapat diketahui bahwa nilai signifikansi untuk pretest dan posttest Karena semua data memiliki nilai Sig.> $\alpha(0,05)$, maka $\mathrm{H} 0$ diterima yang berarti semua data berdistribusi normal.

b) Uji Homogenitas

Uji homogenitas dalam penelitian ini menggunakan chi-Square dengan ketentuan jika nilai signifikansi lebih besar atau $\geq 0,05$ maka dapat dikatakan bahwa dari dua atau lebih kelompok data adalah sama/homogen. Adapun dari perhitungan diperoleh hasil sebagai berikut.

Tabel 6 Hasil Uji Homogenitas

\begin{tabular}{|c|c|c|c|c|}
\hline Variabel & Data & Levene Statistic & Sig. & Keterangan \\
\hline \multirow{3}{*}{ Kognitif } & Pretest & & & \\
\cline { 2 - 3 } & Posttest & 0,006 & 0,940 & Homogen \\
\hline & Pretest & & & \\
\cline { 2 - 2 } & Posttest & 0,298 & 0,587 & Homogen \\
\hline $\begin{array}{c}\text { Psikomotorik } \\
\text { Sangapan }\end{array}$ & Pretest & & & \\
\cline { 2 - 2 } & Posttest & 0,065 & 0,800 & Homogen \\
\hline
\end{tabular}

Berdasarkan table di atas Karena semua data pretest dan posttest untuk aspek penilaian kognitif, psikomotorik dan tanggapan siswa memiliki nilai Sig. $>\alpha(0,05)$, maka H0 diterima dan Ha ditolak yang berarti semua data memiliki varians yang homogen. 


\section{c) Uji Pengaruh (Uji-t)}

Uji perbedaan data hasil pretest dan posttest kelompok perlakuan/treatment dimaksudkan untuk mengetahui apakah permainan tradisional Engklek berpengaruh terhadap peningkatan kemampuan gerak dasar melompat atau tidak. Dalam uji-t ini dapat diketahui jika $\mathrm{t}$ hitung $>\mathrm{t}$ tabel maka perlakuan/treatment yang diberikan mempunyai pengaruh, namun jika $\mathrm{t}$ hitung $<\mathrm{t}$ tabel maka perlakuan/treatment yang diberikan tidak mempunyai pengaruh. Pengujian dengan uji-t digunakan untuk mengetahui apakah variabel bebas secara parsial berpengaruh nyata atau tidak terhadap variabel terikat. Derajat signifikansi yang digunakan adalah 0,05 . Kriteria pengujian adalah diterima apabila hasil perhitungan diperoleh nilai thitung lebih dari nilai derajat kepercayaan.

Tabel 7 Hipotesis untuk Hasil Belajar

\begin{tabular}{|c|c|c|c|c|c|c|}
\hline Data & Rata-Rata & Peningkatan & Thitung & $\begin{array}{c}\text { Ttabel } \\
(\alpha=5 \%, d f=29)\end{array}$ & Sig & Keterangan \\
\hline Pretest & 78,133 & & & & & Berbeda \\
\hline Posttest & 90,383 & $15,68 \%$ & $-10,993$ & 2,045 & 0,000 & Signifikan \\
\hline
\end{tabular}

Berdasarkan hasil perhitungan pada Tabel 4.7, diperoleh nilai Thitung sebesar -10,993 dan Ttabel $(\alpha=5 \%, d f=29)$ sebesar 2,045 dengan nilai signifikansi sebesar 0,000 . Karena $\mid$ Thitung $\mid>$ Ttabel dan Sig. (2-tailed) $<\alpha(0.05)$, maka H0 ditolak dan Ha diterima yang berarti ada pengaruh pemberian permainan englek terhadap pembelajaran daring materi lompat jauh di SMAN 1 Kaliwungu. Dimana rata-rata pretest (sebelum diberikan permainan engklek) hasil belajar lompat jauh sebesar 78,133 dan rata-rata posttest (setelah diberikan permainan engklek) hasil belajar lompat jauh sebesar 90,383. Terjadi peningkatan hasil belajar dari pretest ke posttest yaitu sebesar 15,68\%. Artinya ada efektivitas permainan engklek terhadap pembelajaran daring materi lompat jauh di SMA N 1 Kaliwungu.

\section{PEMBAHASAN}

Selama pandemi Covid-19, proses belajar mengajar di sekolah untuk sementara menggunakan sistem pembelajaran daring yang merupakan sistem pembelajaran tanpa tatap muka secara langsung antara guru dan siswa tetapi dilakukan melalui online. Dalam penelitian ini, melakukan penelitian pada mata pelajaran penjasorkes khususnya materi lompat jauh dengan memanfaatkan permainan tradisional yaitu engklek dalam meningkatkan efektivitas pembelajaran daring materi lompat jauh pada siswa SMAN 1 Kaliwungu. Responden dalam penelitian yaitu siswa SMA N 1 Kaliwungu sebanyak 30 orang.

Hasil belajar diukur berdasarkan aspek penilaian kognitif dan psikomotorik, dimana dilakukan analisis data dengan Paired Sample T-Test untuk mengetahui pengaruh pemberian permainan engklek terhadap hasil pembelajaran daring lompat jauh siswa SMAN 1 Kaliwungu. hasil perhitungan diperoleh $\mid$ Thitung $|=|-10,993 \mid>$ Ttabel $(2,045)$ dan Sig. $(0,000)<\alpha(0.05)$. yang berarti ada pengaruh 
pemberian permainan englek terhadap pembelajaran daring materi lompat jauh di SMAN 1 Kaliwungu. Dimana rata-rata pretest (sebelum diberikan permainan engklek) hasil belajar lompat jauh sebesar 78,133 dan rata-rata posttest (setelah diberikan permainan engklek) hasil belajar lompat jauh sebesar 90,383. Terjadi peningkatan hasil belajar dari pretest ke posttest yaitu sebesar 15,68\% . Efektivitas pemberian permainan engklek terhadap hasil pembelajaran daring materi lompat jauh berdasarkan skor Gain diperoleh persentase sebesar 56,02\% termasuk dalam kategori cukup efektif. Oleh karena itu, pemberian permainan engklek cukup efektif untuk menigkatkan hasil pembelajaran daring untuk materi lompat jauh siswa SMAN 1 Kaliwungu.

Hasil tanggapan siswa terhadap pemberian permainan engklek pada pembelajaran daring materi lompat jauh siswa SMAN 1 Kaliwungu, pada pretest (sebelum perlakuan) diperoleh skor tanggapan siswa sebesar $89,33 \%$ termasuk dalam kategori sangat kuat, sedangkan pada posttest (setelah perlakuan) diperoleh skor tanggapan siswa ssebesar 92,33\%. Hal ini menunjukkan bahwa dengan media permainan tradisional engklek membuat siswa tertarik mengikuti pembelajaran daring materi lompat jauh.

\section{KESIMPULAN}

Berdasarkan hasil analisis data dan pembahasan yang telah dilakukan, maka dapat ditarik kesimpulan, yaitu:

1. a) Terdapat pengaruh yang signifikan hasil tes lompat jauh dengan permainan engklek dimana nilai $(-10,993>2,045)$. Ini artinya pembelajaran daring lompat jauh permainan tradisional Engklek memiliki pengaruh terhadap lompat jauh gaya jongkok.

b) Terdapat peningkatan gerak dasar melompat melalui permainan tradisional Engklek, dengan kata lain permainan tradisional Engklek sangat baik diterapkan dalam pembelajaran disekolah maupun diluar jam sekolah, ini terungkap dengan pengaruh yang telah didapat berdasarkan deskriptif statistik.

\section{SARAN}

1. Bagi peneliti Mendapat tambahan wawasan tentang efektivitas permainan engklek terhadap pembelajaran daring materi lompat juah gaya jongkok sehingga dapat di jadikan sebagai sarana untuk menambah wawasan pengetahuan, untuk bekal pendidik nantinya dan bahan masukan kepada peneliti lainnya.

2. Bagi guru dapat menjadi acuan untuk meningkatkan hasil berlajar siswa khususnya pada olahraga atletik lompat jauh gaya jongkok

3. Bagi siswa di harapkan dapat menambah wawasan dan pengetahuan tentang efektivitas permainan engklek terhadap pembelajaran daring materi lompat jauh gaya jongkok. 


\section{DAFTAR PUSTAKA}

Aep R.- Etor S. (2018), Metode Latihan dan Pembelajaran Bola Voli Untuk Umum, Bandung: Alfabeta.

Albab, A.U. Rahayu, T \& Sugiharto, S. (2016). "Pengembangan alat ring bola basket multiguna untuk pembelajaran pendidikan jasmani kesehatan dan rekreasi (penjasorkes) tingkat sekolah dasar kelas v di kota semarang". Journal Of Physical Uducation And Sport. 5(1), 60-66.

Aprianto, T. Firmanto, G. (2017). "Pengembangan alat pelontar bola voli". Prosiding seminar dan lokakarya fakultas ilmu keolahragaan Universitas Negri Jakarta 2 (01), 58-60.

Arikunto, Suharsimi. (2012). Prosedur penelitian: suatu pendekatan praktek. Jakarta: Rinekacipta.

Dewi, R. (2020). “Pengembangan instrumen tes passing bola voli berbasis digital”. Jurnal Prestasi 4 (1), 9-16.

Hadiana, A. (2020) Pengembangan Media Alat Bantu Smash Bola Voli Pada Mahasiswa FIK Universitas Negeri Medan Tahun 2019.UNIMED. digilib.unimed.ac.id/id/eprint/38979

Muttaqin, I. Winarmo, W.E. dan kurniawan, A. (2016). "Pengembangan model latihan smash bola voli pada kegiatan ekstrakurikuler di smp $n 12$ malang". Jurnal Pendidikan Jasmani. 26 (2), 2016.

Nugroho, E. D (2016). “pengembangan alat pelontar bola multifungsi”. Jurnal pend. Kepelatihan olahraga-S1. 1 (2).

Sugiyono. (2012). Metode penelitian pendidikan : pendekatan kuantitatif, kualitatif, dan $R \& D$. Bandung : Alfabeta.

Sugiyono. (2015). Metode penelitian dan pengembangan. Bandung: Alfabeta.

Syakur, M.A \& Paramitha, S.T. (2017). "Pengembangan alat bantu latihan pelontar bola futsal berbasis mikrokontroler dengan menggunakan software pemograman arduino". Jurnal Terapan Ilmu Keolahragaan. 2 (1), 29-32. 